\title{
Microcirculation in the Labyrinth
}

\author{
J. E. Hawkins, Jr. \\ Kresge Hearing Research Institute and Department of Otorhinolaryngology \\ University of Michigan Medical School, Ann Arbor, Michigan 48109, USA
}

\begin{abstract}
Summary. The inner ear is unique in the number and variety of specialized microvascular networks that furnish blood to its parts. Four distinct capillary networks arranged in parallel supply the structures of the outer wall, and four others those of the spiral lamina. Most of the capillaries are surrounded by pericapillary spaces favoring filtration and reabsorption of fluid. In the guinea pig those of the spiral prominence and outer sulcus show a special pericapillary tissue. The strial capillaries are larger in diameter and are closely invested by strial cells. The blood within them has a higher hematocrit and flows more slowly than elsewhere in the labyrinth.

The arcades of the tympanic lip and basilar membrane receive occasional innervation by fine unmyelinated nerve fibers. A possible role of prostaglandins in controlling the tone of the cochlear microvasculature is suggested. Although it appears unlikely that vascular lesions within the labyrinth could be responsible for the hydrops of Menière's syndrome, devascularization and atrophy of the endolymphatic sac might be contributory factors.
\end{abstract}

Key words: Arcades - Basilar membrane - Capillary networks - Endolymphatic sac - Menière's syndrome - Microhomeostasis - Microvasculature Noise exposure - Pericapillary space - Prostaglandins - Salicylates - Spiral lamina - Spiral ligament - Spiral prominence - Spiral vessels - Stria vascularis - Tympanic lip - Vasomotor fibers.

The normal microhomeostatic mechanisms of the inner ear regulate, inter alia, the volume, the ionic composition, and the rates of formation and reabsorption of the perilymph and endolymph. The functional integrity of these mechanisms is dependent upon an adequate flow of blood through the microvasculature supplying the various sensory, secretory, and reabsorptive areas of the membranous labyrinth.

No other organ of the body possesses such a number of distinct, specialized, microvascular networks as does the inner ear. These networks arise from the 
branches of the internal auditory or labyrinthine artery, which belongs to the basilar rather than to the carotid system, and springs usually, but not always, from the anterior inferior cerebellar artery.

\section{Special Feattres of the Labyrinthine Circulation}

To the classical description of the labyrinthine artery as given by Siebenmann (1894), important observations have been added by Nabeya (1923), Fisch (1969), and Mazzoni (1969) concerning its plural nature and the variations in its origin and branching pattern. Mazzoni (1971) has also shown that it supplies not only the inner ear and the nerves and dura lying within the internal meatus, but that portion of the petrous bone as well which immediately surrounds the meatus.

The distribution of the vestibular branches of the labyrinthine artery and the patterns of the capillary networks intimately associated with the utricular and saccular maculae and the ampullar cristae, have been described by Scuderi and del Bo (1952), by C. A. Smith (1954, 1973), and by the present author (1968); hence they need not be reviewed here. The course of the branches supplying the cochlea, and the capillary networks into which they break up, have also been traced by these authors and by Axelsson (1968), among others. Within the modiolus are to be found the cochlear plexus of Balogh and Koburg (1965), the significance of which is still to be determined, and the thin-walled "glomeruli" of Schwalbe (1887), vessels which Kimura and Ota (1974) have shown to be fenestrated like those of the renal glomeruli. At intervals, branches arise from the spiral modiolar artery, which immediately divide to supply a) the structures of the lateral wall, anb b) the structures of the spiral lamina and the spiral ganglion. If we examine the familiar cross-section of the cochlear duct in the guinea pig, we see these minute vessels in the spiral ligament and stria vascularis, as well as in the spiral limbus and beneath the tympanic lip and pars acuata of the basilar membrane. None are to be seen beneath the pars pectinata, and none in the organ of Corti itself.

\section{Microvasculature of the Lateral Wall}

The vessels of the lateral wall arise from radiating arterioles, which arch over the ceiling of scala vestibuli to the upper margin of the spiral ligament. Some of them can be seen in a dissection of the guinea pig cochlea in which they are stained with benzidine (Fig. 1). In the same type of preparation we can examine the four distinct networks of capillaries that supply these tissues: a) the suprastrial capillaries of the spiral ligament; b) the capillaries of the stria vascularis; c) the longitudinal vessels of the spiral prominence; and d) the vessels that pass downwards behind the stria in the substance of the spiral ligament to the floor of the outer sulcus (Fig. 2). The vessels of the spiral ligament are smaller and more numerous than those that enter the stria vascularis. It is important also to recall that the four networks are arranged in parallel, and not in series as are the glomerular and tubular capillaries of the kidney. Furthermore, we have found no evidence of cross-connections between them. Their general pattern may be examined also in osmic acid-stained specimens from the 


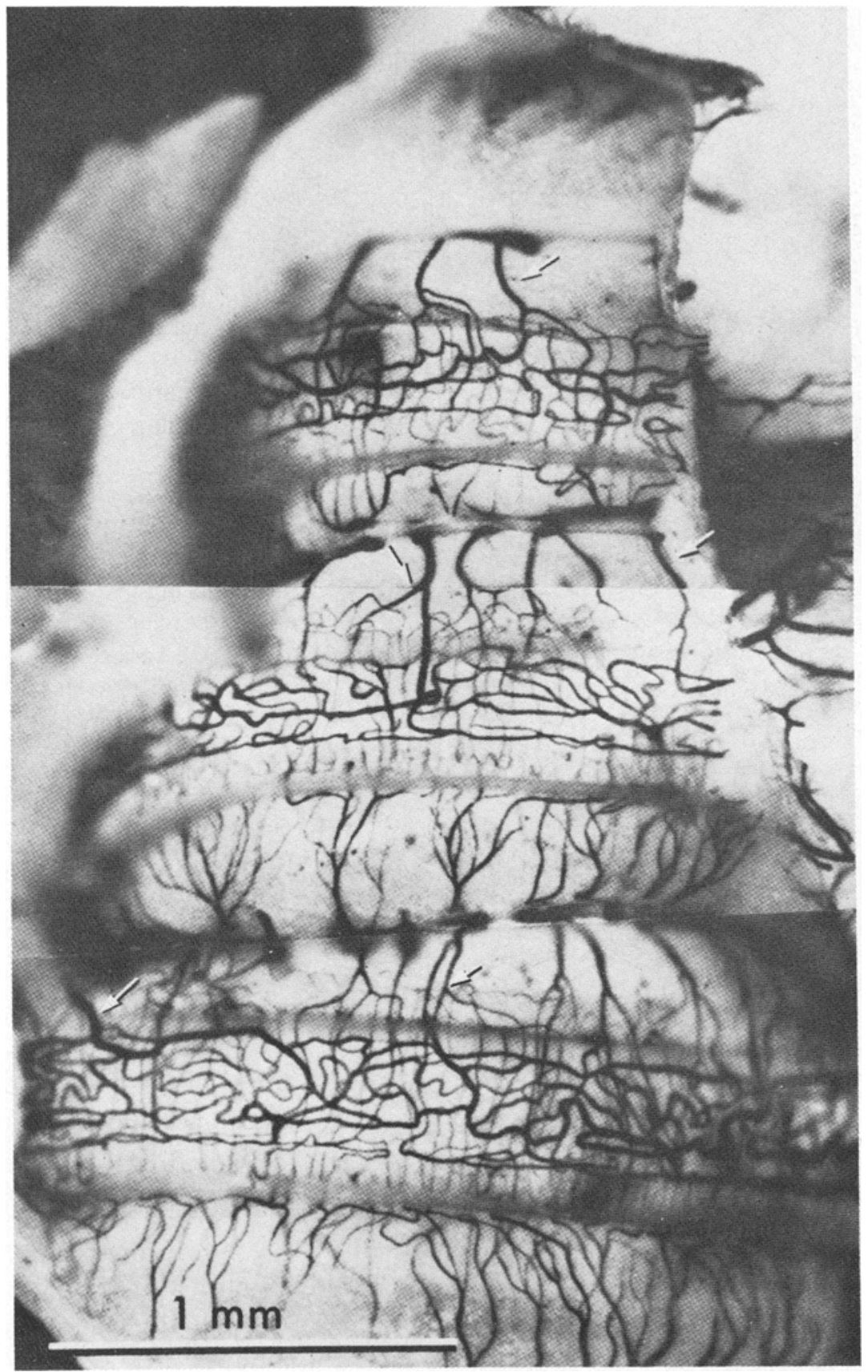

Fig. 1. Vessels of outer wall stained with benzidine. Guinea pig 


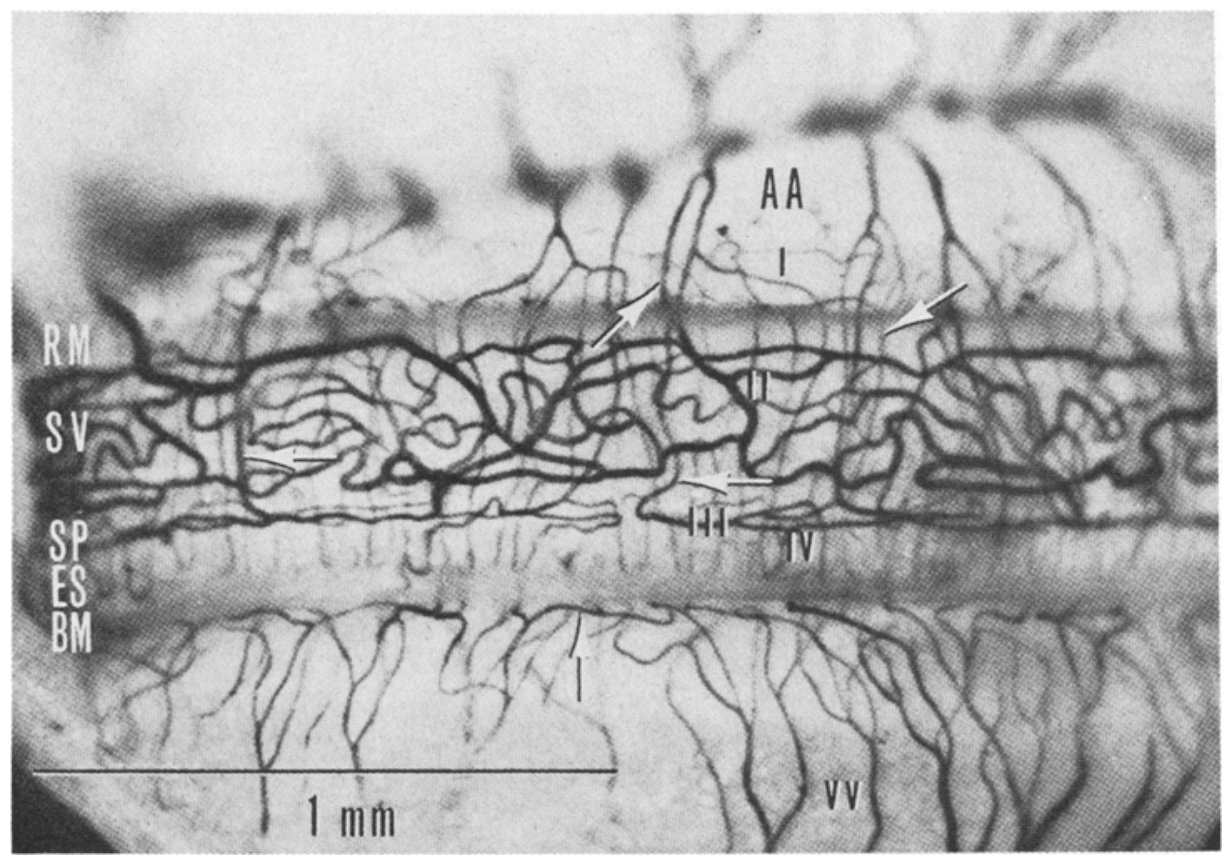

Fig. 2. Vascular patterns of the outer wall of the cochlea. AA, radiating arterioles arching over scala vestibuli. RM, line of insertion of Reissner's membrane at upper margin of SV, stria vascularis, SP, spiral prominence. ES, external sulcus. BM, line of insertion of basilar membrane. VV, venules descending toward floor of scala tympani. Four capillary networks are arranged in parallel: I, suprastrial capillaries; II. strial capillaries; III, capillaries of spiral prominence; IV, capillaries of the spiral ligament and outer sulcus. Only two large vessels enter the strial network, one at the extreme upper left, the other at $\nearrow$. Of the other branches of the radiating arterioles, some go to the spiral prominence $\leftarrow$, others to the outer sulcus $\measuredangle$. Depending upon their proximity to the stria, they are called adstrial or poststrial capillaries of the spiral ligament. Longitudinal vessels (venous capillaries) are seen below the insertion of the basilar membrane $\uparrow$. Guinea pig, basal turn, benzidine stain [From Hawkins et al., Laryngoscope 82, $1091-1104(1972)]$

guinea pig, which have the advantage over material injected with contrast media or stained with benzidine, in that they make it possible to study the relations between the capillaries and the surrounding tissues.

The suprastrial vessels have generous pericapillary spaces, favoring filtration and reabsorption of fluid, whereas the strial vessels are closely invested by the marginal and intermediate strial cells. A curious feature of the strial vessels is the dense packing of the red blood cells within them. The hematocrit here is extraordinarily high, and we know from Perlman and Kimura (1955) that the blood flow is much slower than in the vessels of the spiral ligament. The same contrast is seen between the strial vessels and those of the spiral prominence, where again the red cells move in single file without tight packing (Fig. 3).

Some of the vessels that pass behind the stria descend so closely in contact with its basal cell layer that they deserve a special designation (Fig. 4). I like to refer to them as adstrial capillaries, and thus to distinguish them from the remaining des- 


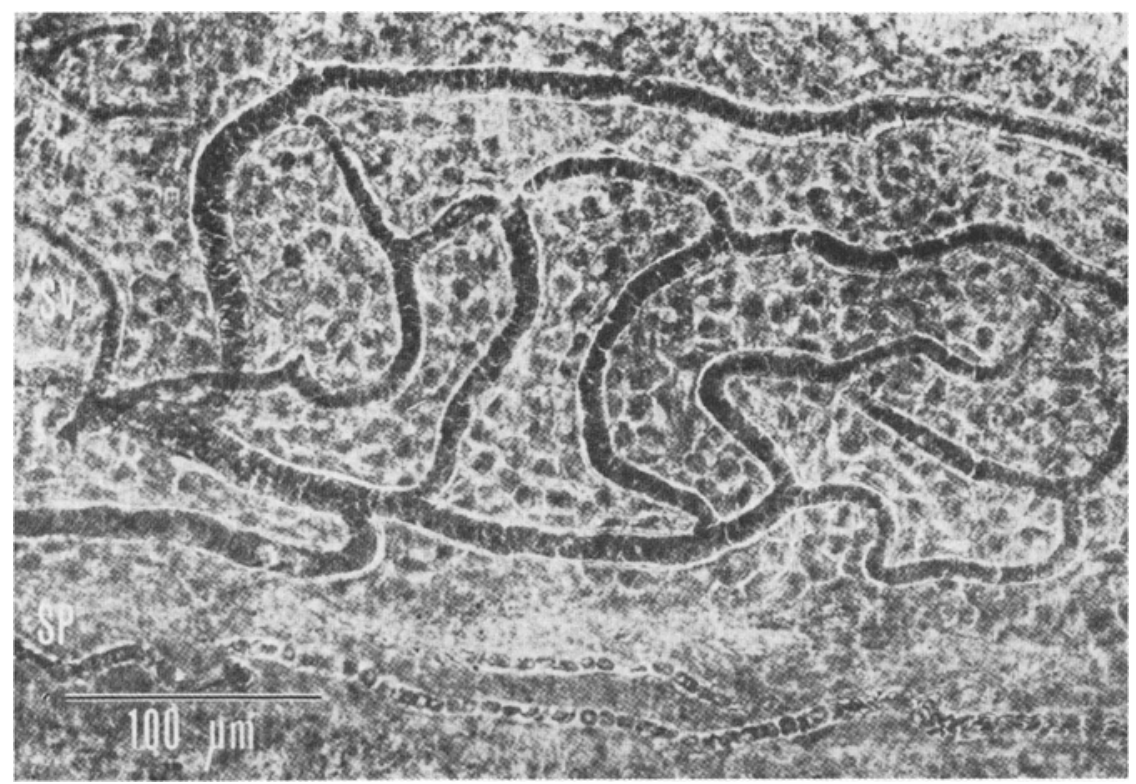

Fig. 3. Capillaries of the stria vascularis, SV, and spiral prominence, SP. Polygonal outlines of the marginal cells of the stria are seen between its anastomosing capillaries. Note differences in pattern, caliber, and degree of filling of the capillaries of the stria and the spiral prominence. Guinea pig. $\mathrm{OsO}_{4}$

cending vessels of the spiral ligament, the poststrial capillaries. Neither fulfills the criteria for arterio-venous shunts, a name frequently given to them, but erroneously (Hawkins, et al., 1972).

Beneath the floor of the outer sulcus, the descending vessels form an alternating pattern with the root cells (Wurzelzellen). Under the electron microscope some of these vessels are seen to be surrounded by an interesting pericapillary tissue, the cells of which have interdigitating processes suggesting a secretory or reabsorptive function (Fig. 5). The vessels of the spiral prominence are similarly surrounded, and presumably have a similar reabsorptive role. Indeed, it appears not unlikely that the outer sulcus vessels with pericapillary tissue may be continuations of the prominence capillaries rather than of adstrial or poststrial vessels.

\section{Microvasculature of the Spiral Lamina}

Among the vessels of the spiral lamina, we find again four sets of capillary networks in parallel: those of the limbus, the spiral ganglion, the tympanic lip, and the basilar membrane. They are chiefly in the form of arcades, a fact that we cannot appreciate when we look at a cross-section of the tympanic lip showing the inner and outer spiral vessels. Their arrangement is much clearer in a dissection from a benzidinestained guinea pig cochlea (Fig. 6). 


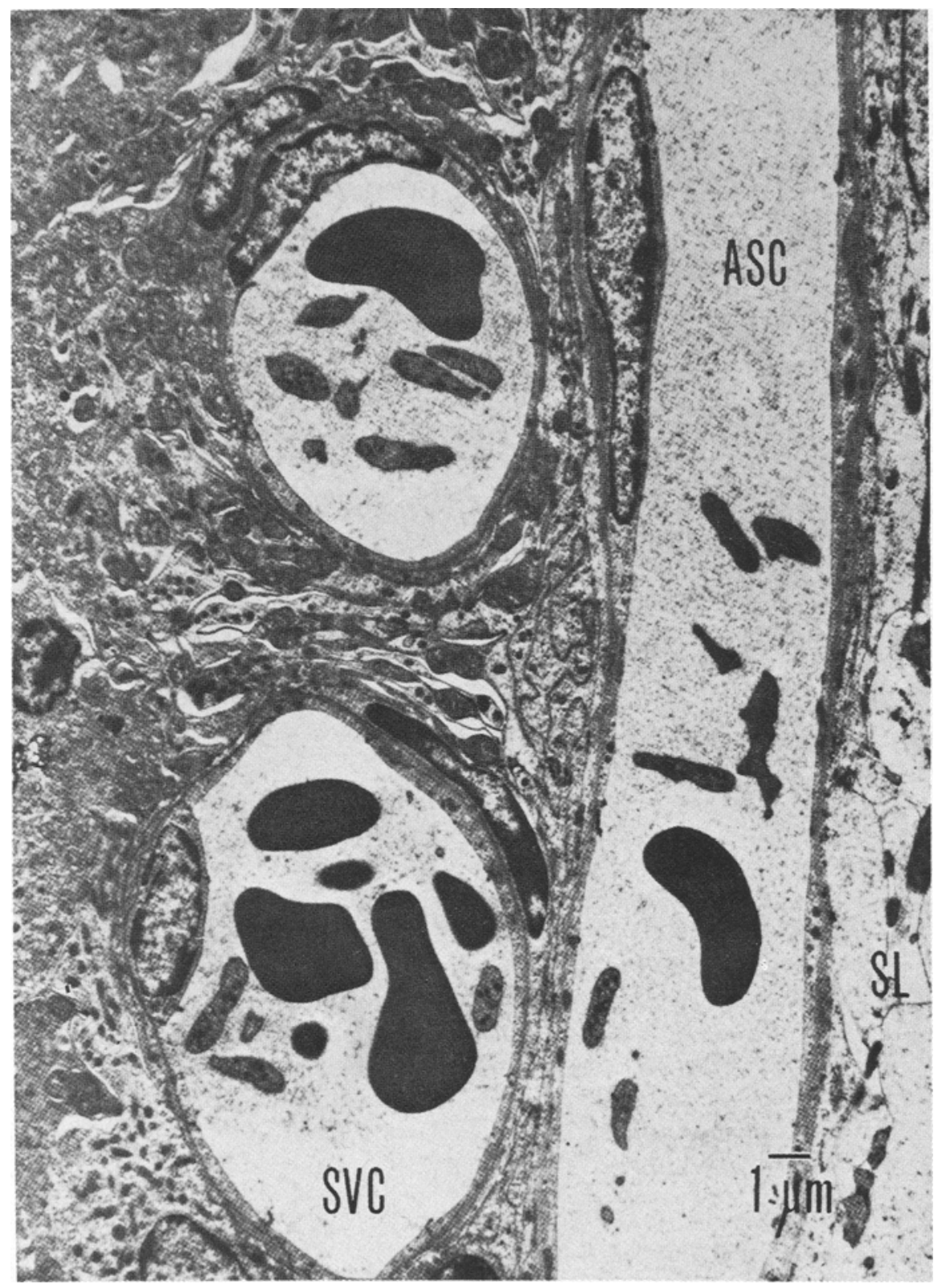

Fig. 4. An adstrial capillary (ASC), adjacent to the basal cell layer of the stria, showing proximity to strial capillaries (SVC). SL, spiral ligament. $\mathrm{OsO}_{4}$. The guinea pig was killed by exsanguination, hence vessels appear almost empty 


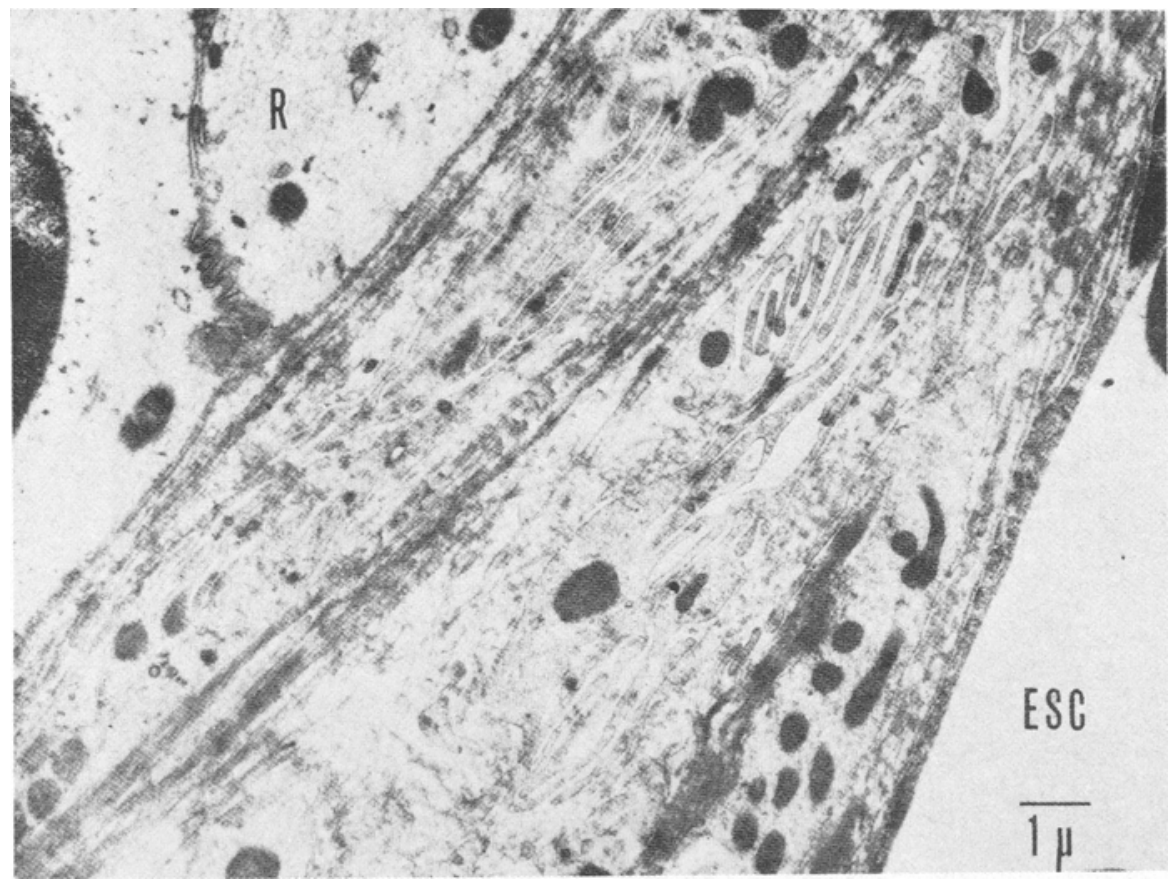

Fig. 5. Detail of the infolded membranes of the pericapillary tissue surrounding an external sulcus capillary, ESC. R, root cell. Guinea pig, lower basal turn. OsO $\mathrm{O}_{4}$, EM (From Hawkins et al., Laryngoscope 82. $1091-1104(1972)]$

The outer and inner spiral vessels (Axelsson's vessel of the basilar membrane, and vessel of the tympanic lip, respectively) are surrounded by generous pericapillary spaces. There is also a remarkably close relation between the latter vessels and the bundles of cochlear nerve fibers as they emerge from the habenula perforata and lose their myelin sheaths on their way to the organ of Corti. Occasionally a thin, beaded nerve fiber, presumably of adrenergic character, is seen to pierce the basilar membrane and to accompany the vessels, making frequent contacts with them (Hawkins, 1973; Wright, 1976).

\section{Mechanisms of Regulation of Blood Flow}

Lawrence (1973) has made extensive cinematographic studies of the blood flow in the vessel of the basilar membrane in the basal turn of the guinea pig cochlea. He has been particularly concerned with the effects of changes in blood flow on the function of Corti's organ as revealed by the cochlear potentials recorded from microelectrodes placed within the tunnel of the Nuel spaces. His films can also be enjoyed from the point of view of pure microvascular aesthetics. Recent evidence that he has obtained in experiments involving temporary anoxia suggests the presence of autoregulatory mechanisms controlling the cochlear blood flow similar to those govern- 


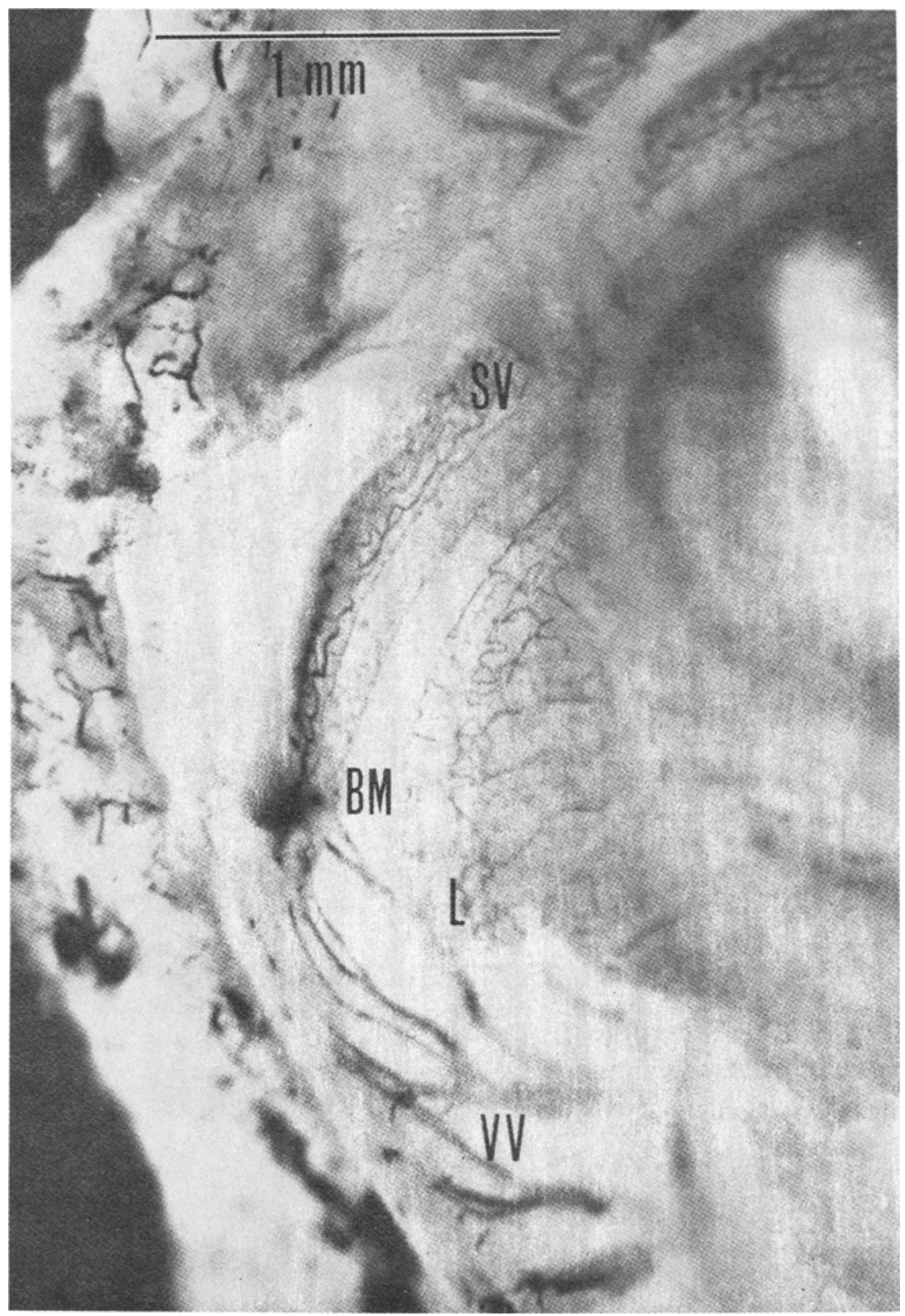

Fig. 6. Capillary patterns of the spiral ligament and stria SV, and the arcades of the spiral lamina and limbus $\mathrm{L}$, on either side of the avascular portion of the basilar membrane BM. VV, veins descending from spiral ligament. Guinea pig, basal coil, benzidine stain 
ing the cerebral blood supply. We know that there are no vasomotor nerves reaching the vessels of the outer wall, and that vasomotion has not been demonstrated (Naumann, 1965). Presumably some form of local hormonal control is present, but we know almost nothing about its nature. The fact, however, that salicylates, like quinine, can cause constriction of cochlear capillaries of the spiral ligament and basilar membrane (Hawkins, 1967), together with the fact that the inhibition of prostaglandin synthetase is inhibited by salicylates, suggests that prostaglandins may be involved in the control of the patency and tone of the cochlear microvasculature.

Among the vascular areas we have considered, one that appears to deserve more attention than it has received heretofore is the suprastrial portion of the spiral ligament located immediately above the insertion of Reissner's membrane. We have observed injury to this region in animals treated with aminoglycosides or exposed to intense noise, as well as capillary vasoconstriction after noise exposure and after treatment with salicylates or quinine. It seems, however, highly improbable that injury to the vessels of this area, which appear to be largely responsible for the formation of the perilymph as a filtrate of the plasma, or any other microvascular lesion, could of itself be primarily responsible for initiating the pathophysiological events that characterize Menière's syndrome.

\section{Microvasculature of the Endolymphatic Sac}

The endolymphatic sac is supplied, according to Bast and Anson (1949), not by the labyrinthine artery but by branches of the posterior meningeal. The folded epithelium of the rugose portion overlies a highly vascular connective tissue. The sac is surrounded by a dense network of capillaries and venous sinuses, draining directly into the lateral sinus. In the intermediate and distal positions of the endolymphatic sac of the guinea pig, Lundquist et al. (1964) have described capillaries with fenestrated endothelium resembling that of the renal glomerular vessels. Atrophic changes resulting from devascularization of the sac with aging could conceivably be a contributory factor in the etiology of Menière's syndrome, but there is insufficient evidence as yet to demonstrate such a causal relationship.

\section{References}

Axelsson. A.: The vascular anatomy of the cochlea in the guinea pig and in man. Acta oto-laryng. Suppl. 243 (1968)

Balogh. K., Koburg. E.: Der Plexus Cochlearis. Arch. Klin. exp. Ohr.-, Nas.-, -u. Kehlk.-Heilk. 185. $638-645$ (1965)

Fisch. U.: The surgical anatomy of the so-called internal auditory artery. In: Disorders of the Skull Base Region (eds. C. A. Hamberger, J. Wersäll), pp. 121-130. New York: J. Wiley and Sons 1969

Hawkins. J. E.. Jr.: Iatrogenic toxic deafness in children. In: Deafness in Childhood (eds. F. MeConnell, P. H. Ward), pp. 156-168. Nashville: Vanderbilt University Press 1967

Hawkins. J. E.. Jr.: Summary. In: Vascular Disorders and Hearing Defects. (ed. A. J. Darin de Lorenzo), pp. 148-166. Baltimore: University Park Press 1973

Hawkins, J. E.. Jr.. Johnsson, L.-G., Preston, R. E.: Cochlear microvasculature in normal and damaged ears. Laryngoscope 82, 1091-1104 (1972) 
Kimura, R. S., Ota, Carol, Y.: Ultrastructure of the cochlear blood vessels. Acta oto-laryng. 77, $231-250(1974)$

Lawrence, M.: In vivo studies of the microcirculation. Adv. Oto-Rhino-Laryng. 20, 244-255 (1973)

Mazzoni, A.: Internal auditory canal arterial relations at the porus acusticus. Ann. Otol. Rhinol. Laryngol. 78, 797-814 (1969)

Mazzoni. A.: Internal auditory artery supply to the petrous bone. Ann. Otol. Rhinol. Laryngol. 81, 13-21(1972)

Nabeya, D.: A study in the comparative anatomy of the blood-vascular system of the internal ear in Mammalia and Homo. Acta Scholae Medicinalis, Kyoto University 6, 1-132 (1923)

Naumann. H. H.: On the vessels of the inner ear. Bibl. Anat. 7, 55-63 (1965)

Perlman, H. B., Kimura, R. S.: Observations of the living blood vessels of the cochlea. Ann. Otol. Rhinol. Laryngol. 64, 1176-1192 (1955)

Schwalbe. G.: Ein Beitrag zur Kenntnis der Circulationsverhältnisse in der Gehörschnecke. In: Beiträge zur Physiologie. C. Ludwig Festschrift, pp. 200-220. Leipzig: F. C. W. Vogel 1887

Scuderi, R., del Bo, M.: La vascularizzažione del labirinto umano. Arch. Ital. Otol. Suppl. 11, (1952)

Siebenmann, F.: Die Blutegefässe im Labyrinthe des menschlichen Ohres. Wiesbaden: J. F. Bergmann 1894

Smith. C. A.: Capillary areas of the membranous labyrinth. Ann. Otol. Rhinol. Laryngol. 63, 435-437 (1954)

Wright. C. G.: Neural damage in the guinea pig cochlea after noise exposure. Acta oto-laryng. (In press) (1976)

\section{Diskussionsbemerkungen}

H. Stupp (Düsseldorf): Wovon hängt der Hydreps ab; ist er abhängig von der Reabsorption der Endolymphe im Saccus oder von der Durchblutung des Innenohres, oder gibt es eine Beziehung zwischen Reabsorption und Blutversorgung. Sowohl Kimura als auch Martinez gelang es, einen Hydrops zu provozieren: Kimura unterband den Saccus endolymphaticus, wogegen Martinez die Blutversorgung des Innenohres durch Embolisierung der Gefäße unterbrach.

J. E. Hawkins (Michigan): Meiner Meinung nach hat beides eine Störung des Ionenaustauschmechanismus und der autonomen Steuerung des Innenohres zur Folge.

A. Axelsson (Göteborg): Sie erwähnten, daß alle Gefäße des Innenohres, mit Ausnahme der Stria vascularis-Gefäße einen Perivaskularraum besitzen. Es scheint mir, daß es einen erheblichen Unterschied zwischen Gefäßen, welche der Endolymphe zugewandt liegen, gibt und solchen, die der Perilymphe zugewandt sind. Soweit man im Phasenkontrastmikroskop erkennen kann, gibt es aber auch einen Perivaskularraum um die Gefäße der Prominentia spiralis, die Limbusgefäße und die Gefäße nahe der Stria vascularis (poststriale Gefäße). Das Spiralgefäß unterhalb der Basilarmembran des Cortischen Organes zeigt sehr weite Perivaskularräume; phaserikontrastmikroskopisch hat man den Eindruck, als ob das Endothel relativ weite Poren besitzt, durch welche Serum in den perivaskularen Raum gelangen kann und in unmittelbare Beziehung mit den dort vorhandenen Nervenfasern tritt; ferner findet man phasenkontrastmikroskopisch Granula um die Spiralgefäße.

J. E. Hawkins (Michigan): Die von Ihnen demonstrierten Perivaskularspalten, beispielsweise im Bereich der Prominentia spiralis, könnten doch wohl auch fixationsbedingt sein. Was die Gefäße des Limbus spiralis betrifft, so sehen wir dort oft perivaskuläre Kanälchen, die den perivaskularen Räumen entsprechen könnten. Wenn Sie die Granula ansprechen, so ist festzustellen, daß man sie sehr häufig im Bereich der Gefäße unterhalb der Basilarmembran der Meerschweinchen findet. Ich glaube nicht, daß es sie beim Menschen gibt. Über ihre Bedeutung ist nichts bekannt.

A. Axelsson (Göteborg): Die Aktivität der ATPase ist von allen Gefäßen der Cochlea am stärksten ausgeprägt in den Gefäßen der Basilarmembran. 
H. H. Kornhuber (U/m): Mich überraschte in Ihren Bildern die dichte Füllung der Gefäße mit Erythrocyten. Ist das nur beim Meerschweinchen zu beobachten?

J. E. Hawkins (Michigan): Wir finden das ganz typisch bei einer Vielzahl von verschiedenen Laboratoriumstieren, wie Meerschweinchen, Kaninchen, Katzen, Ratten, Cinchilla etc. und es scheint, daß diese extreme Kapillarfüllung im Bereich des Ohres etwas ganz besonderes ist. Man findet sie übrigens nicht nur in den Gefäßen der Stria vascularis, sondern besonders auch in ihren zuführenden Gefäßen.

D. Maass (Bingen): Welche Gefäße sind Ihrer Meinung nach am meisten verantwortlich für die Regulation der Durchblutung des Innenohres. Glauben Sie, daß Gefäße, wie beispielsweise die sogenannten Arterio-Spring-Coils oder die ..Glomeruli" von Schwalbe von besonderer regulativer Bedeutung für die Durchblutung des Innenohres sind?

J. E. Hawkins (Michigan): Über die Funktion der sogenannten Schwalbe-Glomeruli ist nichts bekannt.

D. Maass (Düsseldorf): Am Innenohr findet man verschiedene Strukturen, welche für die Durchblutungsregulation prädestiniert sind. Man könnte sie unterteilen in einen myogenen Regulationsabschnitt, wie beispielsweise die Glomeruli mit ihrer stark ausgeprägten Muscularis und der bekannten adrenergen Innervation. Ferner eine humorale und stoffwechselabhängige Regulation und schließlich ist auch an den sogenannten perivaskulären Flüssigkeitsdruck zu denken, der gesteuert wirú von sauren Mucopolysacchariden und Sulfhydrilgruppen, welche das Wasservolumen in den Perivaskularräumen. besonders aber im Bereich des Verlaufs der Gefäße durch den Knochen regulieren. Auch auf diesem Wege wäre eine Durchblutungsregulation möglich. Schließlich wird auch von einer Informationsfortleitung über die Endothelzellen gesprochen.

J. Tonndorf (New York): Gibt es denń tatsächlich arterio-venöse Shunts in Innenohr?

J. E. Hawkins (Michigan): Diese wurden mehrfach belegt und besitzen eine ausgeprägte Muscularis. Sie stehen offensichtlich in einer aktiven regulatorischen Wechseibeziehung zu den Striagefäben. weshalb ich sie als suprastriale Gefäße bezeichne; sie stellen räumlich gesehen eine ebenso große Gefäßeinheit dar, wie der Komplex der Striageräße. denen sie vorgeschaltet sind. Offensichtich versorgen sie auch das Ligamentum spirale.

B. Kellerhals (Bern): Wie stask kann Ihrer Meinung nach ein lokaler Einfluß auf die Funktion sein. Sie erwähnten eine humorale oder autonome Regulation im Inuenoh?

J. E. Hawkins (Michigan): Beim Cinchilla betspielsweise bewirkt Lärm eine extreme Vasokonstriktion. die sowohl die Endothelzellen. wie auch die Pericyten miteiribezieht. Fs scheint möglich zu sein. daß hier Substanzen. wie etwa die Prostaglandine bei der lokalen Regulation eine Rolle spielen; das ist vorerst jedoch nur einc Spekulation.

E. A. Schnieder (Solingen): Es ist gesichert, da? die B!utzirkulation humoral reguliert ist, es ist überhaupt keine aktive Vasomotorik nötig. um die Blutwrteilutig in Innenohr zu regulieren! Die Regulation geht allein über die Fließeigenschaften des Blutes, da wir ja wissen, daß Blut eine ..nicht-Newtonsche Flüssigkeit" ist und eine strukturelle Viskosität besitzt.

A. Axelsson (Göteborg): Die Erscheinung der arterio-venösen Shunts als sogenannte „spring-coils“ gibt es nur beim Meerschweinchen, bei anderen Arten findet man nur spiralig ausgedehnte Gefäßschlingen (Hund). Wie die Physiologen meinen, ist diesen Gefäßschlingen eine druckregulierende Funktion zuzuschreiben. Wir stellten folgendes Experiment an: Wir zerstörten die Stria vascularis und injizierten nach 1-3 Tagen intravenös ein Kontrastmedium. Dies erreichte die Läsion nicht, da die suprastrialen zuführenden Gefäl\}e berets in!erhalb des moliolärın Bereiches verschlossen waren. Ich vermute dahinter eine regulierende Schutzfunktion der Gefaße, welche die Stria versorgen.

C. R. Pfaltz (Basel): Ist der arterielle. der kapilläre, der postkapilläre oder der venöse Schenkel der Innenohrdurchblutung gegen Störungen besonders anfällig? Das hat klinische Bedeutung, da wir für die Therapie den Angriffspunkt kenrienzulernen wünschen.

J. E. Hawkins (Michigan): Man kann noch keine Wertung vornehmen. Wir wissen, dal3 der arterielle Schenkel geschädigt werden kann; doch glaube ich, daß bezüglich der hämostatischen Regulation der kapilläre und venöse Schenkel der wichtigste Ansatzpunkt ist. 